\section{Predictors of knowledge and management practice of Rhesus negative pregnant women among primary health care workers in Kano, Nigeria}

\author{
Auwal Umar Gajida, ${ }^{1}$ \\ Usman Muhammad Ibrahim, ${ }^{2}$ \\ Rabiu Ibrahim Jalo, ${ }^{1}$ Jamilu Tukur, ${ }^{3}$ \\ Takai Idris Usman, ${ }^{3}$ \\ Jaafar Sulaiman Jaafar, ${ }^{4}$ \\ Awwal Musa Borodo, ${ }^{5}$ Nura Abubakar, ${ }^{6}$ \\ Dalha Halliru Gwarzo ${ }^{7}$ \\ ${ }^{1}$ Department of Community Medicine, \\ Bayero University and Aminu Kano \\ Teaching Hospital, Kano State; \\ ${ }^{2}$ Department of Community Medicine, \\ Aminu Kano Teaching Hospital, Kano \\ State; ${ }^{3}$ Department of Obstetrics and \\ Gynecology, Bayero University and \\ Aminu Kano Teaching Hospital, Kano \\ State; ${ }^{4}$ Faculty of Clinical Sciences, \\ Bayero University, Kano State; \\ ${ }^{5}$ Department of Hematology, Murtala \\ Muhammad Specialist Hospital, Kano \\ State; ${ }^{6}$ Department of Biochemistry, \\ Federal University Dutse, Jigawa State; \\ ${ }^{7}$ Department of Hematology, Bayero \\ University Kano and Aminu Kano \\ Teaching Hospital, Kano State, Nigeria
}

\begin{abstract}
Rhesus isoimmunization present significant medico-social problems among rhesus negative women that could be prevented by adopting correct management practices by healthcare providers. This study assessed the predictors of knowledge and management practices of rhesus negative pregnant women among Primary healthcare workers in Kano Metropolis. A descriptive crosssectional study was used to study 424 respondents selected using multistage sampling technique with a response rate of $94 \%$. Data was collected using self-administered semi-structured questionnaire and analyzed with IBM SPSS for Windows, Version 22. Majority of the respondents 354 (88.9) were greater than 24 years of age with mean age of $32.8 \pm 7.1$. More than onehalf $235(59.0 \%)$ of the respondents were female with Hausa speaking respondents by tribe constituting the majority 322 (80.9) healthcare workers studied. Almost twothirds $(62.3 \%)$ of the respondents had good knowledge. However, only 24 (6.0\%) employed correct management practice of rhesus negative pregnancy. Senior staff
\end{abstract}

studied were $60 \%$ more likely $\{\mathrm{AOR}=0.6$, $95 \%$ CI (0.3-0.9) $\}$ to have good knowledge of rhesus negative pregnancy with those in service for 5 or more years to had 2.8 increased likelihood $\mathrm{AOR}=2.8,95 \% \mathrm{CI}$ (1.7-4.7) $\}$ of having good knowledge of Rhesus negative pregnancy. Healthcare workers requesting for blood grouping during ANC services provision were found to have up to 5.2 increased likelihood $\{\mathrm{AOR}=5.2,95 \% \mathrm{CI}(2.7-10)\}$ of having good knowledge of managing rhesus negative pregnancy. Senior staff were found to be $37 \%$ more likely to correctly practice the recommended management of Rhesus negative pregnant women $\{\mathrm{AOR}=0.37$, $95 \% \mathrm{CI}=(0.2-0.9)\}$. Most healthcare workers had good knowledge of rhesus negative pregnancy but wrong management practices. Government should ensure improved practice by putting in place favorable policies that will ensure training and compliance with recommended guideline for managing rhesus negative pregnant women.

\section{Introduction}

Rhesus disease accounts for $97 \%$ of hemolytic disease of the newborn (HDN) which is preventable when measures to prevent feto-maternal hemorrhage in Rh negative pregnancy, antenatal and post-natal immunoprophylaxis with anti-D immunoglobulin are practiced correctly. ${ }^{1}$ Health care providers offering antenatal care services, abortion, post-abortion and postnatal care to rhesus negative pregnant women should therefore know and offer appropriate interventions to prevent isoimmunization by giving Rho (D) immune globulin because, once sensitization has occurred, no amount of RhoGAM (Rho (D) immune globulin)will stop the disease from occuring. ${ }^{1}$

The Rhesus D negative phenotype is low among Africans, about 3.9\% in Kenya, $4.1 \%$ in Guinea, $2.4 \%$ in Cameroon and $4.4 \%$ in Nigeria, ${ }^{2}$ central attributes of primary health care services are accessibility, continuity and client-focused preventive and curative care. The team deals with detection of early signs and symptoms and combines curative and preventive services. ${ }^{3}$ This highlighted the importance of early detection and commencing preventive measures of rhesus isoimmunization at primary healthcare level.

Human resources for health at PHC level should have optimum knowledge on prevention and management of rhesus disease and this will help a long way in reducing the occurrence of Hemolytic disease of
Correspondence: Usman Muhammad Ibrahim, Department of Community Medicine, Aminu Kano Teaching Hospital, PMB 3452 Kano State, Nigeria.

Tel.: +234.8032112497 - Fax: +234.96109753

E-mail: usmanmi2000@gmail.com

Key words: Rhesus negative pregnant women, rhesus isoimmunization, RhoGHAM, Primary healthcare workers.

Contributions: The authors contributed equally.

Conflict of interest: The authors declare no potential conflict of interest.

Funding: None.

Received for publication: 4 February 2019

Revision received: 17 October 2019

Accepted for publication: 17 October 2019.

This work is licensed under a Creative Commons Attribution NonCommercial 4.0 License (CC BY-NC 4.0).

CC Copyright: the Author(s), 2019

Licensee PAGEPress, Italy

Pyramid Journal of Medicine 2019; 2:39

doi:10.4081/pjm.2019.39

new born and its associated consequences. ${ }^{4,5}$

Rhesus isoimmunisation is under studied among Nigerian women and healthcare providers with many questions unanswered in the few studies conducted suggesting the need for management protocol nationwide for this condition to appropriately guide health care providers at various levels, ${ }^{6}$ as the management of women who are Rhesus negative pregnant women has evolved and therefore all pregnant women should be typed and screened for alloantibodies, with an indirect anti-globulin test at the first prenatal visit and again at 28 weeks. ${ }^{7}$

Antenatal management of Rh-negative pregnant women in Sub-Saharan Africa is suboptimal. There are several health system challenges which includes poor socioeconomic status, lack of adequate qualified staff, inadequate referral services and shortage of supplies. ${ }^{8}$

Management with anti-D prophylaxis is expensive and difficult to access in Sub Saharan Africa. Beyond the challenge of access to anti-D prophylaxis, there is lack of alloimmunization prevention during illegal abortions and poor documentation of adequate information in patient's medical notes. ${ }^{2}$ A previous report in Singapore indicated that although obstetricians offer antiD prophylaxis to Rhesus negative women who experience a potentially sensitizing 
event as recommended by the guidelines, not every Rhesus negative woman would have this treatment because of cost. ${ }^{2}$ There is paucity of data on the incidence of Rhesus isoimmunisation in subsequent pregnancies, adverse events or neonatal morbidity. ${ }^{9}$

Hydrops fetalis reduces the chance for a viable outcome by up to $11 \%$, and neonatal and infant outcomes are complicated by the need for repeated transfusions secondary to suppressed erythropoiesis. ${ }^{10}$ Primary health care workers are the first level of contact for preventive and curative services for these pregnant women and therefore need to have good knowledge in the diagnosis and appropriate practices in the management or referral for better pregnancy outcome. This study was aimed to assess the predictors of knowledge and management practices among primary healthcare workers in Kano, Nigeria.

\section{Materials and Methods}

\section{Study area}

Kano is bounded by Jigawa and Bauchi on the East, Plateau and Kaduna states on the south and West respectively, and Katsina State on the North. It is located on longitude $8^{\circ} 31^{\prime} 0.19^{\prime} \mathrm{E}$ and latitude $12^{\circ} 00^{\prime} 0.43 " \mathrm{~N}$. Its densely populated old city is surrounded by $22 \mathrm{~km}$ long wall dating from 13 th century. The city has a long tradition of commerce. ${ }^{11}$

The State Metropolis comprises of Local Governments that lies within the city and they include Kano municipal, Dala, Gwale, Fagge, Nassarawa, Tarauni, Ungogo and part of Kumbotso local government areas. They form the main center of trade and commerce. Based on the 2006 national census, the total population of Kano was $9,401,288$. The projected population for 2016 was 13,076,700. Kano Metropolis, consist of eight local government areas which makes up about 30\% (2016 projected population of $3,931,300$ ) of Kano state population. ${ }^{11}$

The study was conducted in 34 primary health centers within Kano Metropolis that provides antenatal care, routine immunization, outpatient consultation and basic laboratory test services. Health workers providing these services are qualified primary health care Nurse, CHO (Community Health Officer), SCHEW (Senior Community Health Extension Worker), and JCHEW (Junior Community Health Extension Worker). These health care providers are trained to provide services based on the components of primary health care among which is maternal and child health care.

\section{Study design}

Descriptive cross-sectional study was used.

\section{Study population}

All the primary health care workers in Kano Metropolis that were employed more than or equal to 6 months and present at the duty post during the survey were included while healthcare workers who were on annual or sick leave were excluded from the study.

\section{Sample size determination}

Sample of up to 424 was obtained using Fisher's formula for determining minimal sample size for descriptive studies ${ }^{12}$

$$
\frac{\mathrm{n}=\left[\mathrm{Z}^{2} \mathrm{pq}\right]}{\mathrm{d}^{2}}
$$

Based on standard normal (Z) deviate of 1.96 at $95 \%$ confidence interval, prevalence rate from previous study was found to be $49.1 \%=0.491^{13}$ degree of precision of (0.05) and $10 \%$ non-response rate.

\section{Sampling technique}

A three-staged sampling technique was used for selection of eligible respondents. At first, list of all the LGAs within the metropolis was obtained from which 4 LGAs representing 50\% were randomly selected by balloting. At second stage, the list of the facilities in all the selected LGAs was obtained and $50 \%$ of the health facilities in each of the selected LGAs were randomly selected by simple balloting. At the third stage, in the selected health facilities, eligible respondents were proportionately allocated. Hospital staff registers were used to select respondents using the serial number of the hospital general register by balloting. The number obtained was traced and the healthcare workers bearing the serial numbers were interviewed.

\section{Instrument and method of data collection}

A pre-tested structured designed selfadministered questionnaire consisting both opened and closed ended questions was used to collect data. The questionnaire consisted of three sections. The first section obtained information on socio-demographic characteristics of the respondents; the second section asked questions that assessed the respondent's knowledge of Rhesus negative blood, section three explored the management practices of Rhesus negative pregnant women among the respondents.
Advocacy visit was paid to all the hospital heads of the selected hospital and were briefed on the objectives of the research to obtain their permission and cooperation. Four research assistants were trained on the objectives of the study, distribution and retrieval of the questionnaires.

The instrument was pretested among 30 Healthcare workers in PHCs outside the metropolis.

\section{Data management}

Data was analyzed using IBM SPSS Statistics for Windows, Version 22. Quantitative variables were summarized using appropriate measures of central ten dency and dispersion while categorical variables were presented as frequencies and percentages. The dependent/outcome variables are knowledge of rhesus negative and management practice while the independent variables are age, academic qualification/ designation, tribe, marital status, type of facility, and delivery of pregnant women among others.

Up to 10 questions were asked to assess the knowledge of rhesus negative and 12 questions for management practice of rhesus negative pregnant women among the respondents. Correct answer to each question for knowledge of rhesus negative was awarded one point while wrong response was allocated a zero point. Scores of (0-4.9) was considered poor knowledge and $(\geq 5)$ was considered as good knowledge of Rhesus negative pregnancy. ${ }^{14}$ Management practice was equally allocated one point for any correct response and zero point for wrong responses. Management practice score of less than or equal to 5.9 was considered to be wrong practice and a score of $\geq 6$ was considered to be correct practice. ${ }^{14}$ Chi square test or Fishers exact test were used to test for significant association between categorical variables. Binary logistic regression was used to adjust for confounders. A P-value of $\leq 0.05$ was considered significant. The criteria for inclusion of variable into the logistic regression model were "apriori variable", variables significant on bivariate analysis, and a set $\mathrm{P} \leq 0.2$ for variables that were not significant in bivariate analysis. ${ }^{15}$

\section{Ethical considerations}

Ethical approval was obtained from Kano State Health Research Ethics Committee of Kano State Ministry of Health with approval number $\mathrm{MOH} / \mathrm{OFF} / 797 / \mathrm{TI} / 786$. Data was collected from $5^{\text {th }}$ July to $20^{\text {th }}$ September, 2018. All the principles of research ethics were respected throughout the conduct of the research. Consent form was used and 
respondents indicated acceptance to participate in the study by signing the form.

\section{Results}

\section{Socio-demographic characteristics of primary health care workers}

The age of the Primary health care workers ranged from 19 to 51 years with a mean of $32.8 \pm 7.1$. Majority of the respondents were Hausa/Fulani by tribe $382(96 \%)$ with many being greater than 24 years of age. More than one half $235(59 \%)$ were females. Junior community health extension workers constituted the majority 163 $(41 \%)$ in relation to other category of Primary healthcare workers. The median duration in service was 6 years with about two-thirds $240(60.3 \%)$ having spent five or more years in service. More than one-half of the respondents $232(58.3 \%)$ works in Primary health centers. Majority of the healthcare workers studied 363 (91.2\%) offers antenatal services to their clients but only $345(86.7 \%)$ request for routine antenatal investigations to the pregnant women with $336(84.4 \%)$ of them receiving deliveries. Of all the respondents that requested for routine antenatal investigations, only 286 $(71.9 \%)$ request for at least blood grouping (Table 1).

\section{Primary healthcare workers knowl- edge of rhesus negative pregnancy}

The parameters used to assess the knowledge of managing rhesus negative pregnancy are summarized in Table 2 . The knowledge score ranged from 0 to 8 with mean knowledge score of 5.1 \pm 2.0 . Majority
$248(62.3 \%)$ of the respondents had good knowledge but more than one-quarters 150 (37.7\%) had poor knowledge of managing rhesus negative pregnant women as shown in Figure 1. More than two-thirds 289 (70\%) knew the importance of blood grouping but very few $4(1 \%)$ were able to explain rhesus blood grouping as an independent blood grouping method and 237 (59.3\%) knew about RhoGAM with only $142(35.5 \%)$ able to mention the time required for administering it to prevent rhesus isoimmunization.

\section{Primary healthcare workers man- agement practice of rhesus negative pregnancy}

The parameters used to assess the management practice of rhesus negative pregnancy are summarized in Table 2. The Minimum management practice score was 0 and the maximum was 10 with a range of 10 median of 1.6. Majority of the respondents 374 (94\%) wrongly manage rhesus negative pregnant women as shown in Figure 1. Only $50(12.5 \%)$ responded to sending pregnant women for blood grouping all the time, very few $9(2.3 \%)$ of the respondents ever diagnosed rhesus negative pregnancy. More than one-quarters of the respondents requested for blood donation for safe keeping before delivery as shown in Table 1.

\section{Discussion}

The medico-social problems associated with hemolytic disease of newborn are numerous, and is a preventable disease when measures to prevent feto-maternal hemorrhage in Rh negative pregnancy when antenatal and post-natal immune-prophylaxis with anti-D immunoglobulin (Ig) are practiced correctly. ${ }^{1}$ This emphasized the importance of having good knowledge on rhesus negative pregnancies which is key in ensuring correct management practices by healthcare workers especially at primary healthcare level.

It was found in this study that about two-thirds of the respondents had good knowledge of rhesus negative blood but majority wrongly managed the rhesus negative pregnant women. This corroborated the

Table 1. Socio-demographic characteristics of the respondents.

Variable
$\begin{aligned} & \text { Frequency } \\ & (\mathrm{n}=398)\end{aligned}$

\begin{tabular}{lcc} 
Age group & & \\
18-24 & 44 & 11.1 \\
$>24$ & 354 & 88.9 \\
Gender & & \\
Male & 163 & 41 \\
Female & 235 & 59 \\
\hline Tribe & & \\
Hausa & 322 & 80.9 \\
Fulani & 60 & 15.1 \\
Yoruba & 7 & 1.8 \\
Igbo & 1 & 0.2 \\
Others & 8 & 2.0 \\
Marital status & & \\
Married & 241 & 60.6 \\
Single & 130 & 32.6 \\
Divorced & 17 & 4.3 \\
Widow & 10 & 2.5 \\
\hline
\end{tabular}

\section{Designation/Qualification}

$\begin{array}{lll}\text { Nurse } & 10 & 2.5\end{array}$

$\begin{array}{lll}\text { CHO } & 69 & 17.3\end{array}$

$\begin{array}{lll}\text { SCHEW } & 82 & 20.6\end{array}$

JCHEW $\quad 163 \quad 41$

$\begin{array}{lll}\text { Others } & 74 & 18.6\end{array}$

Number of years in service (years)
$1-4$$\quad 158 \quad 39.7$

$\begin{array}{lll}1-4 & 158 & 39.7 \\ \geq 5 & 240 & 60.3\end{array}$

Type of Facility

$\begin{array}{lll}\text { PHC } & 232 & 58.3\end{array}$

$\begin{array}{lrr}\text { CHC } & 59 & 14.8\end{array}$

$\begin{array}{lll}\text { Dispensary } & 32 & 8.1\end{array}$

$\begin{array}{lll}\text { Others } & 75 & 18.8\end{array}$

ANC Services
Yes

\begin{tabular}{lcc} 
No & 363 & 91.2 \\
& 35 & 8.8 \\
\hline
\end{tabular}

ANC Investigation

$\begin{array}{lll}\text { Yes } & 345 & 86.7\end{array}$

$\begin{array}{lll}\text { No } & 18 & 4.5\end{array}$

$\begin{array}{lll}\text { No ANC } & 35 & 8.8\end{array}$

$\begin{array}{lll}\text { Type of ANC Investigations } & & \\ \text { None } & 112 & 28.1 \\ \text { At least Blood grouping } & 286 & 71.9\end{array}$

\begin{tabular}{lcc}
\hline Deliver Pregnant Women & & \\
Yes & 336 & 84.4 \\
No & 62 & 15.6 \\
\hline
\end{tabular}

Figure 1. Distribution of knowledge of Rhesus negative and management practice of Rhesus negative pregnant women among primary health care workers. 
Table 2. Parameters used to assess knowledge and management practice of Rhesus negative pregnant women among healthcare workers.

\begin{tabular}{|c|c|c|c|}
\hline Knowledge of Rhesus negative & $\begin{array}{l}\text { Frequency } \\
(\%)\end{array}$ & Management practice & $\begin{array}{l}\text { Frequency } \\
(\%)\end{array}$ \\
\hline Do you know about blood grouping system? & $289(70.0)$ & Have you ever diagnosed a Rhesus negative pregnant woman? & $9(2.3)$ \\
\hline If yes how many types do you know? & $118(29.5)$ & Do you provide health education to pregnant women during ANC? & $41(10.3)$ \\
\hline Do you know about Rhesus blood grouping system? & $4(1.0)$ & If yes, what is the area of emphasis for women with Rhesus negative blood? & $66(16.5)$ \\
\hline Rhesus blood group can be categorized into? & $231(57.8)$ & Do you test for blood group of pregnant women during ANC? & $50(12.5)$ \\
\hline $\begin{array}{l}\text { Does women with Rhesus negative blood faces } \\
\text { any danger during pregnancy? }\end{array}$ & $376(94.0)$ & If yes, what do you do when you get a Rhesus negative pregnant woman? & $29(7.3)$ \\
\hline If yes what danger(s) do they face? & $124(31.0)$ & If the above answer is why? & 45 (11.3) \\
\hline $\begin{array}{l}\text { What leads to development of these dangers } \\
\text { in a Rhesus negative pregnant woman }\end{array}$ & $300(75.0)$ & When do you give RhoGAM? & $71(17.8)$ \\
\hline $\begin{array}{l}\text { What can you do to assist a Rhesus negative } \\
\text { pregnant woman? }\end{array}$ & $221(55.3)$ & $\begin{array}{l}\text { Do you request for blood donation for safe keeping before delivery } \\
\text { by the relatives of Rhesus negative mother? }\end{array}$ & $114(28.5)$ \\
\hline Do you know about RhoGAM? & $237(59.3)$ & Do you like attending to Rhesus negative pregnant women? & $76(19.0)$ \\
\hline \multirow{3}{*}{$\begin{array}{l}\text { If yes, when is RhoGAM given to a Rhesus negative } \\
\text { pregnant woman for prevention } \\
\text { of rhesus iso-immunisation. }\end{array}$} & $142(35.5)$ & Have you attended to any Rhesus negative pregnant woman before? & $40(10.0)$ \\
\hline & & Have you ever referred a Rhesus negative woman to another facility? & $33(8.3)$ \\
\hline & & If yes, how often do you refer a Rhesus negative woman to other facilities & $79(19.8)$ \\
\hline
\end{tabular}

Table 3. Predictors of primary health care workers knowledge and management practice of Rhesus negative pregnant women.

\begin{tabular}{|c|c|c|c|c|c|c|c|c|c|c|}
\hline \multirow[t]{2}{*}{ Variable } & \multicolumn{3}{|c|}{ Knowledge } & \multicolumn{2}{|c|}{ Logistic regression } & \multicolumn{3}{|c|}{ Management practice } & \multicolumn{2}{|c|}{ Logistic regression } \\
\hline & Poor & Good & P-value $\left(\chi^{2}\right)$ & AOR $(95 \% \mathrm{CI})$ & P-value & Wrong & Correct & P-value $\left(\chi^{2}\right)$ & AOR $(95 \% \mathrm{CI})$ & P-value \\
\hline $\begin{array}{c}\text { Age group } \\
\qquad \begin{array}{c}18-24 \\
>24\end{array}\end{array}$ & $\begin{array}{l}21(47.7) \\
129(36.4)\end{array}$ & $\begin{array}{l}23(52.3) \\
225(63.6)\end{array}$ & 0.1 & $0.6(0.3-1.3)$ & 0.2 & $\begin{array}{c}44(100) \\
330(93.2)\end{array}$ & $\begin{array}{c}0(0) \\
24(6.8)\end{array}$ & $\dagger 0.09$ & & \\
\hline $\begin{array}{l}\text { Gender } \\
\qquad \text { Male } \\
\text { Female }\end{array}$ & $\begin{array}{l}51(31.3) \\
99(42.1)\end{array}$ & $\begin{array}{l}112(68.7) \\
136(57.9)\end{array}$ & $0.03^{*}$ & $0.5(0.3-0.9)$ & $0.012^{*}$ & & & & & \\
\hline $\begin{array}{l}\text { Tribe } \\
\text { Hausa } \\
\text { Others }\end{array}$ & $\begin{array}{c}143(37.4) \\
7(43.8)\end{array}$ & $\begin{array}{c}239(62.6) \\
9(56.3)\end{array}$ & 0.6 & & & $\begin{array}{l}358(93.7) \\
16(100)\end{array}$ & $\begin{array}{l}24(6.3) \\
0(0)\end{array}$ & $\dagger 0.6$ & & \\
\hline $\begin{array}{l}\text { Marital status } \\
\text { Married } \\
\text { Unmarried } \\
\end{array}$ & $\begin{array}{l}86(35.7) \\
64(40.8)\end{array}$ & $\begin{array}{c}155(64.3) \\
93(59.2)\end{array}$ & 0.3 & & & $\begin{array}{l}223(92.5) \\
151(96.2)\end{array}$ & $\begin{array}{l}18(7.5) \\
6(3.8)\end{array}$ & 0.2 & $0.7(0.27-1.9)$ & 0.5 \\
\hline $\begin{array}{l}\text { Designation/Qualification } \\
\text { Senior staff } \\
\text { Junior staff }\end{array}$ & $\begin{array}{l}45(28.0) \\
105(44.3)\end{array}$ & $\begin{array}{l}116(72.0) \\
132(55.7)\end{array}$ & $0.001^{*}$ & $0.6(0.3-0.9)$ & $0.028 *$ & $\begin{array}{l}145(90.1) \\
299(96.6)\end{array}$ & $\begin{array}{l}16(9.9) \\
8(3.4)\end{array}$ & $0.01 *$ & $0.37(0.2-0.9)$ & $0.028 *$ \\
\hline $\begin{array}{l}\text { Number of years in service } \\
\begin{array}{c}1-4 \\
\geq 5\end{array}\end{array}$ & $\begin{array}{l}81(51.3) \\
69(28.7)\end{array}$ & $\begin{array}{l}77(48.7) \\
171(71.3)\end{array}$ & $0.000 *$ & $2.8(1.7-4.7)$ & $0.000 *$ & $\begin{array}{l}152(96.2) \\
222(92.5)\end{array}$ & $\begin{array}{l}6(3.8) \\
18(7.5)\end{array}$ & 0.1 & & \\
\hline $\begin{array}{l}\text { Type of Facility } \\
\text { PHC } \\
\text { CHC } \\
\text { Dispensary } \\
\text { Others }\end{array}$ & $\begin{array}{l}76(32.8) \\
17(28.8) \\
24(75.0) \\
33(44.0)\end{array}$ & $\begin{array}{l}156(67 .) \\
42(71.2) \\
8(25.0) \\
42(56.0)\end{array}$ & $0.000 *$ & $1.0(0.8-1.2)$ & 0.9 & & & & & \\
\hline $\begin{array}{l}\text { ANC Services } \\
\text { Yes } \\
\text { No }\end{array}$ & $\begin{array}{l}122(33.6) \\
28(80.0)\end{array}$ & $\begin{array}{l}241(66.4) \\
7(20.0)\end{array}$ & $0.00^{*}$ & $0.4(0.1-2.8)$ & 0.4 & $\begin{array}{l}339(93.4) \\
35(100)\end{array}$ & $\begin{array}{c}24(6.6) \\
0(0)\end{array}$ & $\dagger 0.3$ & & \\
\hline $\begin{array}{l}\text { ANC Investigation } \\
\text { Yes } \\
\text { No } \\
\text { No ANC }\end{array}$ & $\begin{array}{l}112(32.5) \\
10(55.6) \\
28(80.0)\end{array}$ & $\begin{array}{l}233(67.5) \\
8(44.4) \\
7(20.0)\end{array}$ & $0.000 *$ & $1.3(0.4-4.2)$ & 0.6 & & & & & \\
\hline $\begin{array}{l}\text { Type of ANC Investigations } \\
\text { None } \\
\text { At least Blood grouping }\end{array}$ & $\begin{array}{l}75(67.0) \\
75(26.2)\end{array}$ & $\begin{array}{l}37(33.0) \\
211(73.8)\end{array}$ & $0.000^{*}$ & $5.2(2.7-10)$ & $0.00^{*}$ & & & & & \\
\hline $\begin{array}{l}\text { Deliver Pregnant Women } \\
\text { No } \\
\text { Yes }\end{array}$ & $\begin{array}{l}37(59.7) \\
113(33.6)\end{array}$ & $\begin{array}{l}25(40.3) \\
223(66.4)\end{array}$ & $0.000 *$ & $0.8(0.3-2.0)$ & 0.6 & $\begin{array}{c}62(100) \\
312(92.9)\end{array}$ & $\begin{array}{c}0(0) \\
24(7.1)\end{array}$ & $\dagger 0.04$ & & \\
\hline $\begin{array}{l}\text { Knowledge } \\
\text { Poor }\end{array}$ & & & & & & $150(40.0)$ & $224(59.9)$ & & & \\
\hline
\end{tabular}

*Statistically significant; AOR, Adjusted odds ratio; $\chi^{2}$,Chi square; $\dagger$, Fishers exact. 
result from India in which the main cause of sensitization identified was lack of awareness particularly in rural areas where the mothers are not routinely tested for their ABO Rh blood group. ${ }^{1}$

This study found most primary healthcare workers greater than 24 years of age to had better knowledge of managing rhesus negative pregnant women, though more female respondents were studied, being a male was found to be a significant predictor of having good knowledge of managing rhesus negative pregnancy $\{\mathrm{AOR}=0.5,95 \%$ $\mathrm{CI}=(0.3-0.9)\}$, this may be due to the fact that men in this setting are more likely to advance their educational qualification which was also found to be a significant predictor of good knowledge of managing rhesus negative pregnancy $\{\mathrm{AOR}=0.6,95 \%$ $\mathrm{CI}=(0.3-0.9)\}$ and participation in workshops outside the state may improve their knowledge (Table 3). Implementation of a program of routine antenatal anti-D prophylaxis (RAADP) has led to a significant decline in the numbers of women becoming sensitized in most developed countries, good number of women who are not lucky enough to have access in Sub-Saharan Africa continue to be affected. ${ }^{2}$ A step towards achieving this, is good knowledge of the condition and ensuring compliance with correct practice

In addition, healthcare workers who have being in service for five or more years were better in terms of knowledge of managing rhesus negative pregnancy and were 3 times more likely to have good knowledge when compared with those that were less than 4 years in service $\{\mathrm{AOR}=2.8,95 \% \mathrm{Cl}$ $(1.7-4.7)\}$, this may be explained by the possibility of receiving training that could improve their knowledge. There was a statistically significant association between working in primary healthcare center and having good knowledge of managing rhesus negative pregnant women $(\mathrm{P}<0.001)$, this may be due to employment and placement of higher cadre primary healthcare workers compared to other facilities at Local government level.

Conducting at least blood grouping during antenatal services was found to be a significant predictor of having good knowledge of managing rhesus negative pregnancy $\{\mathrm{AOR}=5.2,95 \% \mathrm{CI}=(2.7-10)\}$, this may not be unconnected with information, education and communication that is expected to be regularly conducted to ensure blood safety and avoidance of blood transfusion reaction in all centers that offer blood grouping and transfusion services. There was also statistically significant association between taking deliveries in the facilities and having good knowledge of managing rhesus negative pregnancies $(\mathrm{P}<0.001)$.

There are differences in local circumstances among countries, both in respect to the organization of their health systems and the availability of resources to deliver the recommended interventions. Furthermore, differences also exist in the composition and training of health care personnel in the area of managing their patients, ${ }^{4}$ The curriculum of senior healthcare workers at primary healthcare level consist of reproductive health component that is involved in ensuring the concept of safe motherhood, in that line, this study identified that being a senior staff (CHO, Nurse, and SCHEW) was a significant predictor of correct management practice of rhesus negative pregnancy $\{\mathrm{AOR}=0.37,95 \% \mathrm{CI}=(0.2-0.9)\}$ and there was a statistically significant association between having good knowledge and correct practice of managing rhesus negative pregnant women $(\mathrm{P}<0.001)$. This study is limited by paucity of local literatures that studied predictors of knowledge and management practices of rhesus negative pregnant women among Primary healthcare workers.

\section{Conclusions}

Good knowledge was significantly associated with correct practice of managing rhesus negative pregnancy. Healthcare workers should ensure that all the necessary investigations are conducted including blood grouping during routine antenatal visits to identify Rhesus negative pregnant women and correctly manage the condition to prevent Rhesus isoimmunization. In addition, government should ensure training and adherence to Antenatal care guideline by all the healthcare workers with respect to correct management of Rhesus negative pregnant women.

\section{References}

1. Moitra B, Kumari A, Sahay PB. Obstetrical and Perinatal Outcome in Rhesus Antigen Negative Pregnancy. Int J Sci Study 2016;3:124-9.

2. Erhabor O, Isaac Z, Yakubu A, Adias TC. Abortion, ectopic pregnancy and miscarriages in Sub Saharan Africa: Challenges of Rhesus isoimmunisation in Rhesus negative women. Open J Obstet Gynecol 201;3:15-26.

3. Maeseneer M, Willems S, De Sutter M, et al. Primary health care as a strategy for achieving equitable care: a literature review commissioned by the Health Systems Knowledge Network. 2007.
Available from: https://biblio.ugent.be/ publication/396406/file/1041490.pdf

4. Abdulmalik J, Kola L, Fadahunsi W, et al. Country Contextualization of the Mental Health Gap Action Programme Intervention Guide: A Case Study from Nigeria. PLoS Med 2013;10:e1001501.

5. Ayiasi RM, Criel B, Orach CG, et al. Primary healthcare worker knowledge related to prenatal and immediate newborn care: A cross sectional study in Masindi, Uganda. BMC Health Serv Res 2014;14:1-11.

6. Okeke TCT, Ocheni S, Nwagha UIU, Ibegbulam OGO. The prevalence of Rhesus negativity among pregnant women in Enugu, Southeast Nigeria. Niger J Clin Pract 2012;15:400-2.

7. Fung FK, Eason E, Crane J, et al. Prevention of $\mathrm{Rh}$ alloimmunization. J Obstet Gynaecol Canada 2003;25:76573.

8. Osaro E, Charles AT. Rh isoimmunization in sub-saharan africa indicates need for universal access to anti-rhd immunoglobulin and effective management of d-negative pregnancies. Int $\mathrm{J}$ Womens Health 2010;2:429-37.

9. McBain RD, Crowther CA, Middleton P. Anti-D administration in pregnancy for preventing Rhesus alloimmunisation. Cochrane Database Syst Rev 2015;9:CD000020.

10. Moise KJ. Management of Rhesus Alloimmunization in Pregnancy. Obstet Gynecol 2008;112:164-76.

11. National Bureau of Statistics. 2006 population census figures by states and LGAs. Available from: http:/www.nigerianstat.gov.ng. Accessed 10th March 2018

12. Lwanga SK, Lemeshow S. Sample sizedetermination in health studies, a practical manual. Publication of the World Health Organization. 1991:1-3. http://apps.who.int/iris/handle/10665/4 0062

13. Wee WW, Kanagalingam D. The use of anti-D immunoglobulins for rhesus prophylaxis: Audit on knowledge and practices among obstetricians. Singapore Med J 2009;50:1054-7.

14. Orimadegun AE, Ojebiyi AO. Primary health workers' knowledge and practices relating to neonatal jaundice in Ibadan, Nigeria. Afr J Prm Health Care Fam Med 2017;9:a1081.

15. Lawan UM, Gajida AU, Ibrahim UM, Gora MM. Occupational Hazard Perception and Safety Practices among workers of small-scale Industries in Kano, Nigeria. Kanem J Med Sci 2016;1:36-44. 